\title{
EXTRACTION OF PHENOLIC COMPOUNDS AS ANTIOXIDANTS FROM SOME PLANTS AND THEIR CYTOTOXIC ACTIVITY AGAINST BREAST CANCER CELL LINE
}

\author{
RABAB OMRAN ${ }^{1 *}$, ZAHRAA M AL-TAEE ${ }^{1}$, HAYDER O HASHIM ${ }^{2}$, MOHAMMED J AL-JASSANI ${ }^{3}$ \\ ${ }^{1}$ Department of Biology, College of Science, University of Babylon, Al-Hillah City, Babel, Iraq. ${ }^{2}$ Department of Clinical Laboratory Sciences, \\ College of Pharmacy, University of Babylon, Babel, Iraq. ${ }^{3}$ DNA Research Center, University of Babylon, Babel, Iraq. \\ Email: omranaljelawi@gmail.com
}

Received: 21 March 2017, Revised and Accepted: 20 April 2017

ABSTRACT

Objective: The objective of the study was to study the antioxidants and cytotoxic activities of phenolic extracts of some plants against breast cancer and normal cell lines.

Methods: Phenolics were extracted from different parts of some plants (15) such as seeds, fruits, leaves, and rhizomes using methanol: ethanol: HCl: Distilled water at a ratio 50:29:1:20 (v:v:v:v). The contents of phenolics and flavonoids were estimated using gallic acid and quercetin as standards, respectively. The antioxidant activity was determined by 2,2-azinobis-(3-ethylbenzothiazoline-6-sulfonic acid) radical scavenging assay. Phenolic flavonoids were partially purified by adsorption chromatography using a silica gel column from selected plants and assayed their cytotoxic activity against breast cancer cell line Michigan Cancer Foundation-7 (MCF-7) and a normal cell line of non-tumorigenic fetal hepatic cell line (WRL-68).

Results: The Cinnamomum zeylanicum extract had the highest phenolic and flavonoid contents were followed by Lawsonia inermis, Citrullus colocynthis, Syzygium aromaticum, Peganum nigrum, and Phoenix dactylifera. The antioxidant activity of Curcuma longa, P. dactylifera, C. colocynthis, Solanum melongena, and $C$. zeylanicum extracts had the highest ability to scavenge the free radicals. The acetone fraction of $P$. dactylifera and $C$. colocynthis extracts had the minimum inhibition dose that kills 50\% of cells inhibitory concentration 50 values $156.91 \mu \mathrm{g}$ and $1055.06 \mu \mathrm{g}$ against MCF-7 and $372.86 \mu \mathrm{g}$ and $153.8 \mu \mathrm{g}$ against WRL-68, respectively. While the $S$. melongena extract had less effect on both cell lines.

Conclusions: Phenolics as antioxidant substances had moderate or variable effectiveness on normal and cancer cell lines, and the highest concentrations were cancerous poison impact may be on normal cells over than cancer cells.

Keywords: Phenolics, Antioxidants, Phoenix dactylifera, Citrullus colocynthis, Solanum melongena.

(c) 2017 The Authors. Published by Innovare Academic Sciences Pvt Ltd. This is an open access article under the CC BY license (http://creativecommons. org/licenses/by/4. 0/) DOI: http://dx.doi.org/10.22159/ajpcr.2017.v10i7.18673

\section{INTRODUCTION}

Plants are very important sources of secondary metabolites such as phenolic compounds and antioxidants, which having variable functions in growth, photosynthesis, reproduction, and other primary processes are not known yet. In other hand, they are important in pharmaceutical industries, particularly in Asia [1]. Flavonoids and phenolic acids are the main antioxidant substance of plants have the ability to scavenge free superoxide radicals, anti-aging, reducing the risk of cancer, and enhance human immunity. Flavonoids are consisting a general variety of substances that play a key role in protecting biological systems against the harmful effects of oxidative processes on macromolecules, such as carbohydrates, proteins, lipids and DNA [2].

Oxidative stress is very important, if not crucial, to initiate and develop many current conditions and diseases, including inflammation, autoimmune diseases, cataract, cancer, Parkinson's disease, aging, and arteriosclerosis. Antioxidants are the components that significantly retard or prevent the oxidation of an oxidizable substrate when present in low concentrations [2-4]. The main antioxidants are flavonoids, which proved to be more effective than Vitamin C, E and carotenoids; They protect human, animal, and plant cells against the damaging effects of free radicals (reactive oxygen species [ROS]). An imbalance between antioxidants and free radicals results in oxidative stress, possibly will consequence to cellular damage [2,3]. The antioxidant properties of phenolics are mediated by the following mechanisms: (1) Scavenging radical species like ROS/reactive nitrogen species (RNS), (2) suppressing ROS/RNS formation by inhibiting some enzymes or chelating trace metals involved in free radical production, (3) up-regulating or protecting antioxidant defense. The reduced activity of phenolics depends on the number of free hydroxyl groups in the molecular structure, which would be supported by steric hindrance [2]. Luteolin is a flavone that acts as an antioxidant, free radical scavenger, cancer prevention agent, immune system modulator, and anti-inflammatory agent. Flavonoids from some plants such as tea, chocolate, cocoa, fruits, and vegetables are highly potent antioxidant compounds that help to decrease the occurrence of cancer, heart failure, and diabetes [2,4-6].

Cancer is a multifactorial disease, including genetic, metabolic, physical, environmental and chemical factors, in which each plays a direct and/or indirect role in the initiation and deterioration of cancers. A diet with high ingesting of antioxidant-rich vegetables and fruits reduces the risk of many cancer types, meaningfully suggesting that these antioxidants could be effective substances to inhibit or prevent cancer [1,7-9]. Polyphenols were isolated from different plants like young ginger (Zingiber officinale) including kaempferol, quercetin, rutin, and gallic acid, were inhibited the growth of human breast cancer cell lines such as MCF-7 and 3,4-methylenedioxyamphetamine (MDA)MB-231 [10]. Furthermore, polyphenols were isolated from green tea and strawberry such as epicatechin, epigallocatechin, quercetin, kaempferol, coumaric acid, anthocyanins and ellagic acid, prevented the growth of human breast, prostate (LNCaP, DU-145) tumor cell lines, oral (KB, CAL-27) and colon (HT-29, HCT-116) [11,12].

The objective of this study was to extraction of phenolic compound as antioxidant agents from some local plants and study their ability to prevent breast cancer cell line growth. 


\section{MATERIALS AND METHODS}

\section{Plant raw materials}

The plant raw materials, including 7 Iraqi plants, in addition to bananas which imported from Somalia were purchased from a grocery store, and the dill and myrtle leaves were collected from gardens in Babylon Province, Iraq, during April in 2014; The other plants (6 plant products) were purchased from local markets, which they were the imported products from India and China; Table 1 showed the plant materials, families, the source and part used in this study. The plant raw materials were washed with distilled water and dried in shade separately at room temperature. If most of the moisture has been removed, the plant material can be ground in a blender or mill to produce small particles $(<2 \mathrm{~mm})$. After that, these samples (100-500 g) were stored in glass containers at $-24^{\circ} \mathrm{C}$ until extraction was performed.

\section{Chemicals}

All solvents, acids and some materials, including methanol $(\mathrm{MeOH})$, ethanol (EtOH), acetone, hexane, dimethyl sulfoxide (DMSO), $\mathrm{HCl}$, silica gel, and $\mathrm{Na}_{2} \mathrm{CO}_{3}$ were purchased from Gainland Chemical Co. Ltd., UK. The other materials were purchased from Sigma-Aldrich Co., USA, which including $\mathrm{AlCl}_{3}$, quercetin, gallic acid, Folin-Ciocalteu reagent, 3-[4, 5 - dimethylthiazoyl]-2, 5-diphenyltetrazolium bromide (MTT dye), 2,2`-azinobis-(3-ethylbenzothiazoline-6-sulfonic acid) (ABTS) and potassium persulfate.

\section{Optimal phenolic extraction of plant samples}

Optimum extraction method parameters will vary depending on the sample matrix. Each plant sample may require different temperatures and solvent mixtures $[9,13]$. When extracting antioxidants from plants, a good solvent mixture is alcohol-water (ratios will vary with different plant samples) which soaking for $24 \mathrm{~h} 30^{\circ} \mathrm{C}$ and shaking rate $120 \mathrm{rpm}$ in shaker incubator. However, each plant sample (20 g) was extracted twice with different extraction systems $(400 \mathrm{ml})$ at the ratio of raw material to solvent $1: 20$ by soaking for $24 \mathrm{~h} 30^{\circ} \mathrm{C}$ in the shaker incubator (JSSI-200 Series, JSR, Korean). The extraction systems were composed from $\mathrm{H}^{2} \mathrm{O}-\mathrm{EtOH}$ mixture (10-80\%), the second extraction system was composed from EtOH:MeOH:HCl: $\mathrm{H}_{2} \mathrm{O}$ at ratios 30:49:1:20; 40:39:1:20; 50:29:1:20; 60:19:1:20 and 70:9:1:20. The plant extracts were decanted, filtered under vacuum, concentrated in a rotary evaporator (IKA HB10, Germany) at $40^{\circ} \mathrm{C}$, and then the concentrated extracts were stored at $-24^{\circ} \mathrm{C}$ for further purification.

Partial purification of phenolics by adsorption chromatography The resulting concentrated crude extract from selected plants was partially purified using adsorption chromatography by silica gel (mesh 60-120). The slurry of silica gel was prepared by soaking with hexane [14-16], subsequently with absolute EtOH and then poured into the column $(25 \times 2.5 \mathrm{~cm})$ and washed with EtOH for one an hour to obtain better packing. Concentrated plant extract $(5 \mathrm{ml})$ was loaded into the silica gel column and eluted successively with different solvents by using batch ways (500 $\mathrm{ml}$ for each) $95 \% \mathrm{EtOH}, 70 \%$ acetone, 30\% acetone and then distilled water. The solvent was run at $4 \mathrm{ml} /$ minutes and $5 \mathrm{ml}$ fraction volume were collected. Frequently each fraction was checked by absorbance at $275 \mathrm{~nm}$ for phenolic acids and isoflavonoids and $340 \mathrm{~nm}$ for flavonoids and coumestans using a spectrophotometer (PD-303 ultraviolet [UV], APEL Co., Ltd., Japan) [14-16], then estimating phenolic and flavonoid compounds content. Finally, the positive fractions for each solvent were combined together and stored at $-24^{\circ} \mathrm{C}$ for further analysis.

\section{Determination of total flavonoids}

The total flavonoids were determined by the method described by Chaves et al. [17]. The extracts were diluted with distilled water. To the $2 \mathrm{ml}$ of each test sample was added the same volume of $2 \%(\mathrm{w} / \mathrm{v}) \mathrm{AlCl}_{3}$ solution in methanol. This mixture remained undisturbed for $10 \mathrm{~min}$ before the UV spectrophotometric reading at $415 \mathrm{~nm}$ wavelength. The blank was prepared by replacing $\mathrm{AlCl}_{3}$ solution by methanol. The total flavonoids were determined by the calibration curve using quercetin as standard at concentrations of $0,6.25,12.5,25$, and $50 \mu \mathrm{g} / \mathrm{ml}$ and expressed in $\mu \mathrm{g}$ equivalent of quercetin. The results were expressed as micrograms of quercetin/ $\mathrm{ml}$ of the extract and $\mathrm{mg}$ quercetin equivalent per gram dry weight (mg QE/g DW) of plant.

\section{Total phenolic content}

The Folin-Ciocalteu method was used to determine the total polyphenols, using gallic acid as a standard [17], a $1 \mathrm{ml}$ of diluted test sample was added to $1 \mathrm{ml}$ of $1 \mathrm{~mol} / \mathrm{l}$ Folin-Ciocalteu reagent. This mixture remained undisturbed for 2 minutes before the addition of $2 \mathrm{ml}$ of $20 \%(\mathrm{w} / \mathrm{v})$ $\mathrm{Na}_{2} \mathrm{CO}_{3}$ solution and left undisturbed for $10 \mathrm{~min}$. After that, the reading was performed by a spectrophotometer (OPTIZEN POP - Korea) at $757 \mathrm{~nm}$. The calibration curve was obtained with a stock solution of gallic acid ( $1 \mathrm{mg} / \mathrm{ml})$, from which dilutions were made at concentrations of $5,10,15,20,25,30,35$, and $40 \mu \mathrm{g} / \mathrm{ml}$. The total content of polyphenols was expressed in microgram equivalents of the standard used and $\mathrm{mg}$ gallic acid equivalent (mg GAE/g DW) of plant.

\section{Determination of antioxidant activity}

Antioxidant activity was determined using ABTS radical scavenging assay, which was carried out following the method of Budrat and Shotipruk $[18,19]$ with some modifications. The extract was diluted in series in water (from $5 \mu \mathrm{g} / \mathrm{ml}$ to $5 \mathrm{mg} / \mathrm{ml}$ ) and each diluted samples were added to the $\mathrm{ABTS}^{*+}$ stock solution, which included $7 \mathrm{mM}$ ABTS and $2.45 \mathrm{mM}$ potassium persulfate, with the volume ratio of 1:10 (sample solution: $\mathrm{ABTS}^{*+}$ stock solution). The $\mathrm{ABTS}^{*+}$ stock solution had an absorbance of $0.70 \pm 0.02$ units at $734 \mathrm{~nm}$ using the spectrophotometer. The solutions were mixed using a vortex and the

Table 1: Plant materials and their sources

\begin{tabular}{|c|c|c|c|c|}
\hline Binomial name & Common name & Family & Source & Part used \\
\hline A. ampeloprasum & Leek & Amaryllidaceae & Iraq & Leaves \\
\hline A. graveolens & Dill & Apiaceae & Iraq & Leaves \\
\hline C. sinesis & Tea plant & Theaceae & India & Leaves \\
\hline C. annuum & Capsicums & Solanaceae & Iraq & Fruit \\
\hline C. zeylanicum & Cinnamon & Lauraceae & China & Bark \\
\hline C. colocynthis & Desert gourd & Cucurbitaceae & Iraq & Fruit \\
\hline C. longa & Turmeric & Zingiberaceae & India & Rhizomes \\
\hline M. acuminata & Bananas & Musaceae & Somalia & Fruit Peels \\
\hline M. communits & Myrtle & Myrtaceae & Iraq & Leaves \\
\hline P. nigrum & Black pepper & Piperaceae & India & Fruit \\
\hline P. dactylifera & Date palm & Arecaceae & Iraq & Seeds (pits) \\
\hline S. longena & Aubergine & Solanaceae & Iraq & Fruit Peels \\
\hline S. aromaticum & Cloves & Myrtaceae & India & Seeds \\
\hline V. vinifera & Grapevine & Vitaceae & Iraq & Fruit \\
\hline
\end{tabular}

A. ampeloprasum: Allium ampeloprasum, A. graveolens: Anethum graveolens, C. sinesis: Camellia sinesis, C. annuum: Capsicum annuum, C. zeylanicum: Cinnamomum

zeylanicum, C. colocynthis: Citrullus colocynthis, C. longa: Curcuma longa, L. inermis: Lawsonia inermis, M. acuminate: Musa acuminate, M. communits: Myrtus communits,

P. nigrum: Piper nigrum, P. dactylifera: Phoenix dactylifera, S. melongena: Solanum melongena, S. aromaticum: Syzygium aromaticum, V. vinifera: Vitis vinifera 
mixtures were incubated at room temperature for $10 \mathrm{~min}$, and then the absorbance was taken at $734 \mathrm{~nm}$ using the spectrophotometer. For comparing, the antioxidant activity of the extracts obtained at various concentrations of sample producing $50 \%$ reduction of the radical absorbance inhibitory concentration $50\left(\mathrm{IC}_{50}\right)$ was used as an index. $\mathrm{IC}_{50}$ values, which defined as the concentration of test material needed to scavenge $50 \%$ of ABTS radical present in the test solution. Lower $\mathrm{IC}_{50}$ value reflects better ABTS radical scavenging activity. The $\mathrm{IC}_{50}$ values for various extracts were found from the plots of percent inhibition (PI) versus the corresponding concentration of the sample. The values of PI were calculated using the following equation:

$$
\operatorname{PI}(\%)=\left[1-\left(\frac{\mathrm{At}}{\mathrm{Ar}}\right)\right] \times 100
$$

Where At and Ar are absorbance of test samples and absorbance of the reference, respectively.

\section{Cytotoxic activity by MTT assay}

To determine the cell viability by colorimetric assay using 3-[4, 5 -dimethylthiazoyl]-2, 5-diphenyltetrazolium bromide (MTT dye), two kinds of cells were employed in this work: The human breast cancer cell line Michigan Cancer Foundation-7 (MCF-7) and the Normal human hepatic cells (non-tumorigenic fetal hepatic cell line WRL-68). Briefly, $100 \mu \mathrm{l}$ cell suspension was added onto the flat-bottomed micro-culture plate wells, each line in a separated plate, for the two cell lines and treated them with $100 \mu \mathrm{l}$ partially purified plant extract, incubated for $24 \mathrm{~h}$, centrifuged to remove the dead cells. An aliquot of $100 \mu \mathrm{l}$ from $2 \mathrm{mg} / \mathrm{ml}$ MTT dye was added to each well and incubation was continued for a further $4 \mathrm{~h}$, then $50 \mu \mathrm{l}$ of solubilization solution of DMSO was added into each well. The experiment was performed in triplicate. After complete solubilization of the dye, the absorbance of the colored solution obtained from living cells was read at $620 \mathrm{~nm}$ with an ELISA reader. The mean absorbance for each group of replicates was calculated. The percentage viability of cells exposed to various treatments was obtained as follows [20,21]:

$$
\% \text { cell viability }=\left(\frac{\text { Mean absorbance of treated sample }}{\text { Mean absorbance of control sample }}\right) \times 100
$$

The control was the non-treated cultures in all experiments that contained cells in the medium only. This assay was held at the Centre for Natural Product Research and Drug Discovery, Department of Pharmacology, Faculty of Medicine, University of Malaya/Kuala Lumpur, Malaysia.

\section{Statistical analyses}

Data were analyzed using SPSS version 22 software Fisher's exact with a significant value of $<0.05$.

\section{RESULTS AND DISCUSSION}

Phenolic flavonoids were extracted from different plants (15 plants), including different plant parts such as leaves, fruits, bark, and rhizobium (Table 1). First, the extraction method was optimized using various percentages of $\mathrm{H}_{2} \mathrm{O}$-EtOH mixtures $(0-80 \%)$ to extract phenolic compounds from 2 plants and then the best volume fraction was selected. The other system which composed from EtOH:MeOH:HCl: $\mathrm{H}_{2} \mathrm{O}$ at various proportions was optimized to select the best solvent system to extract flavonoids from different plants.

The total flavonoids content was estimated using the method described by Chaves et al. [17], and total flavonoids were expressed as mg QE/gDW, through the calibration curve of quercetin (Fig. 1). Furthermore, the total phenolic content was determined using the Folin-Ciocalteu method which modified by Chaves et al. [17]. The principle of this method is based on phenolic substances reduces Folin-Ciocalteu reagent in the presence of sodium carbonate. This reduction causes a color change between 745 and $765 \mathrm{~nm}$. Total phenolic content of plant extracts was expressed as mg GAE/gDW through the calibration curve with gallic acid (Fig. 2)

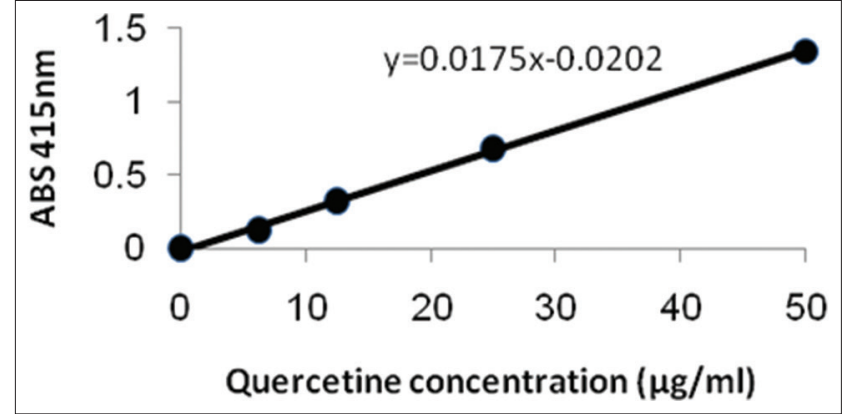

Fig. 1: The calibration curve of quercetin's standard

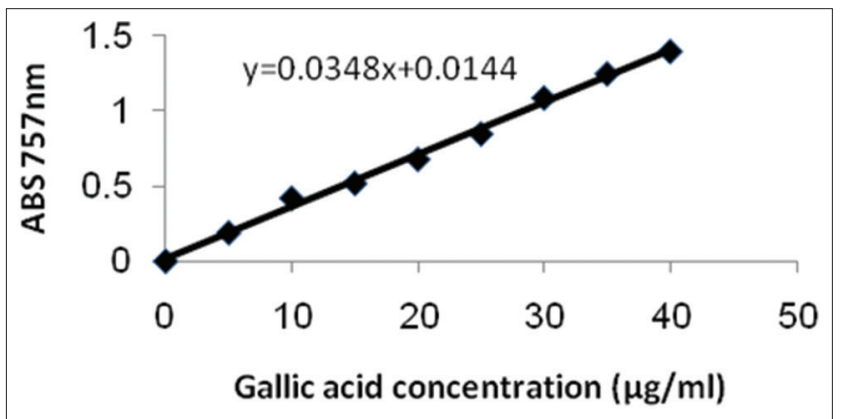

Fig. 2: The calibration curve of gallic acid's standard

Fig. 3 shows the extraction yield of total phenolic and flavonoids using various volume ratios of ethanol $(0-80 \%)$ when other extraction conditions were as follows: Temperature $30^{\circ} \mathrm{C}$, extraction time $24 \mathrm{~h}$ with shaking rate $120 \mathrm{rpm}$, the ratio of solvent to raw material was 20:1, and the extraction number 2 . The extraction yield of flavonoids was ranged from $1.20 \pm 0.064 \mathrm{mg} \mathrm{QE} / \mathrm{gDW}$ to $3.59 \pm 0.030 \mathrm{mg} \mathrm{QE} / \mathrm{gDW}$ and the total phenolics was ranged from $15.82 \pm 0.034 \mathrm{mg}$ GAE/gDW to $34.75 \pm 0.023 \mathrm{mg}$ GAE/gDW from A. ampeloprasum. Whereas the extraction of flavonoids and total phenolics from $C$. colocynthis were ranged from $1.93 \pm 0.033 \mathrm{mg} \mathrm{QE} / \mathrm{gDW}$ to $3.6 \pm 0.100 \mathrm{QE} / \mathrm{gDW}$ amg QE/gDW, and from $21.53 \pm 0.503 \mathrm{mg}$ GAE/gDW to $41.1 \pm 0.100$ mg GAE/gDW, respectively. The best flavonoid and phenolic extraction of both plant samples were occurred in the concentration $50 \%$ ethanol ( $\mathrm{p}=0.008$ and 0.001 at a level 0.05 ), and there was a nonsignificant variation of the phenolic extraction with increasing ethanol concentration over $50 \%$. The highest yield of flavonoids was $3.59 \pm 0.030 \mathrm{mg} \mathrm{QE} / \mathrm{gDW}$ and $3.6 \pm 0.100 \mathrm{mg}$ QE/gDW obtained from $A$. ampeloprasum and $C$. colocynthis respectively, using the percentage 50:50 of ethanol:water mixture, as well as the yield of phenolic compounds appeared the same extraction results. But increasing the concentration from $60 \%$ to $80 \%$, slightly decreased the yield of flavonoids from both. Rostagno et al. [22] also found $50 \%$ as the best ethanol-water mixture for extraction of isoflavones by using the microwave, but in this study, we used shaker incubator at $30^{\circ} \mathrm{C}$ in the rate $120 \mathrm{rpm}$ for $24 \mathrm{~h}$. The highest phenolic concentration was obtained when ethanol-water mixture $(\leq 50 \%)$ was used (Fig. 3). This is related to the dielectric properties of the solvent. Dielectric properties have an important role for interaction of the plant raw material with shaking. It is known that ethanol-water mixture has higher dielectric properties than pure water and absolute ethanol [23]. The synergistic effect that is revealed by ethanolwater mixture can be explained by the hydrogen bonding between water and ethanol which increases the dielectric properties. As a result, this solvent type can increase its efficiency by adding another solvent more polar like methanol, in addition to supplement this system with $1 \% \mathrm{HCl}$ to release the bounded phenolic compound from cell or tissue structures. Hence, the other solvent mixture was used containing EtOH:MeOH: $\mathrm{HCl}: \mathrm{H}_{2} \mathrm{O}$ to obtain the best phenolics and flavonoids extraction from plants raw materials. 


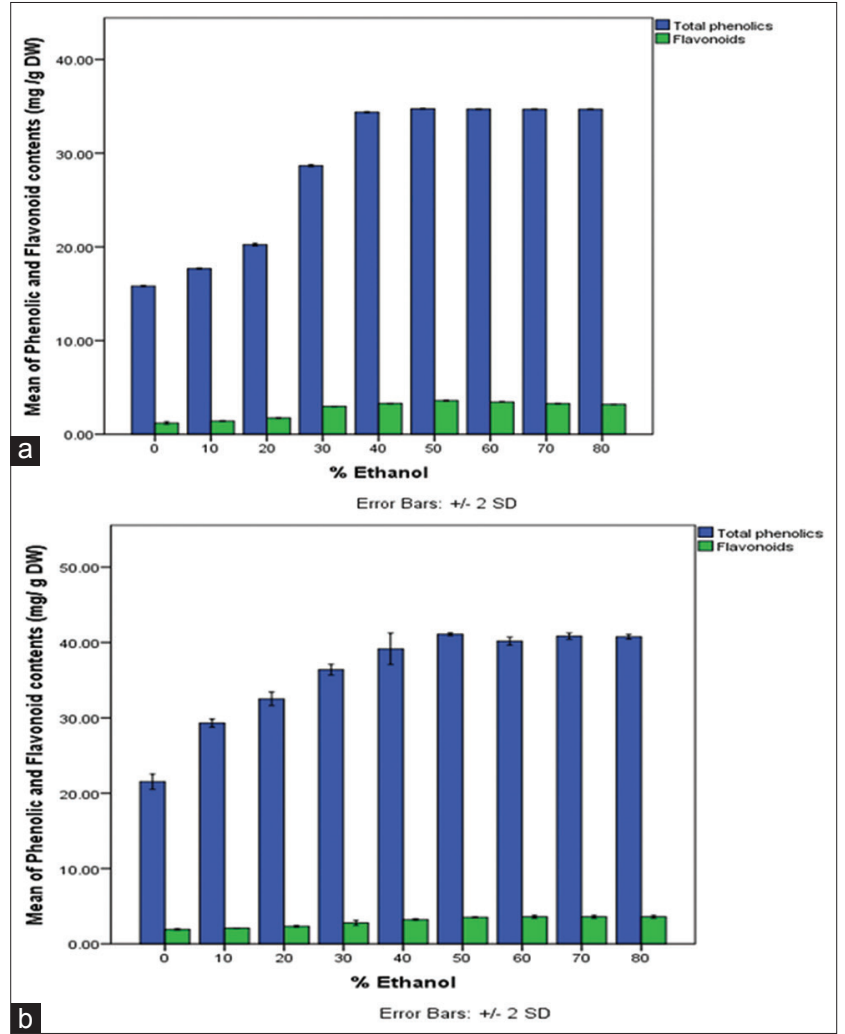

Fig. 3: Extraction total flavonoids and total phenolics from Allium ampeloprasum and Citrullus colocynthis using various ethanol ratios. (a) A. ampeloprasum, (b) C. colocynthis. Extraction conditions where temperature $30^{\circ} \mathrm{C}$, extraction period of $24 \mathrm{~h}$ with shaking rate $120 \mathrm{rpm}$, solvent to raw material ratio 20:1, and the extraction number 2

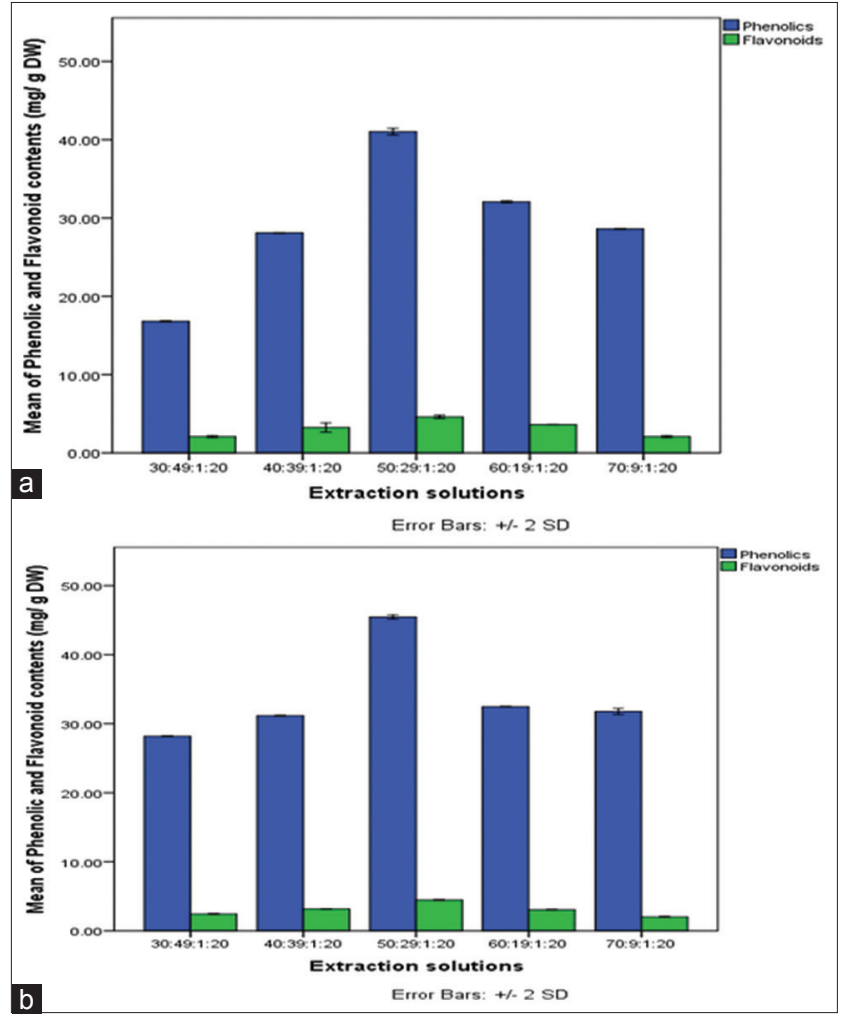

Fig. 4: Extraction total flavonoids and total phenolics from Allium ampeloprasum and Citrullus colocynthis using various ratios of

EtOH:MeOH:HCl:H $\mathrm{H}_{2}$. (a) A. ampeloprasum, (b) C. colocynthis.

Extraction conditions where temperature $30^{\circ} \mathrm{C}$, extraction period of $24 \mathrm{hrs}$ with shaking rate $120 \mathrm{rpm}$, solvent to raw material ratio 20:1, and the extraction number 2

Table 2: Plants extracts and total phenolic and flavonoid compounds and antioxidant activity

\begin{tabular}{|c|c|c|c|c|}
\hline Plant & Dry weight of extract $(\%) \pm$ SD & $\begin{array}{l}\text { Total phenolics } \\
(\mathrm{mgGAE} / \mathrm{gDW}) \pm \mathrm{SD}\end{array}$ & $\begin{array}{l}\text { Flavonoids } \\
(\mathrm{mgQE} / \mathrm{gDW}) \pm \mathrm{SD}\end{array}$ & $\begin{array}{l}\text { Antioxidant } \\
\text { activity }(\mu \mathrm{g} / \mathrm{ml}) \pm \mathrm{SD}\end{array}$ \\
\hline A. ampeloprasum & $10.03 \pm 0.06^{*}$ & $40.75 \pm 0.05^{*}$ & $5.10 \pm 0.02 *$ & $92.00 \pm 1.00$ \\
\hline A. graveolens & $5.1 \pm 0.10$ & $6.83 \pm 0.06$ & $0.83 \pm 0.01$ & $720.67 \pm 0.53$ \\
\hline C. sinesis & $4.1 \pm 0.10$ & $15.10 \pm 0.10^{*}$ & $1.95 \pm 0.01$ & $104.00 \pm 1.00$ \\
\hline C. annuum & $8.10 \pm 0.10$ & $35.16 \pm 0.15$ & $3.26 \pm 0.01$ & $193.00 \pm 1.53$ \\
\hline C. zeylanicum & $9.10 \pm 0.10$ & $148.26 \pm 0.15^{* *}$ & $29.63 \pm 0.51^{*}$ & $95.33 \pm 0.58$ \\
\hline C. colocynthis & $5.04 \pm 0.05$ & $45.5 \pm 0.15^{*}$ & $4.48 \pm 0.02 *$ & $87.33 \pm 1.53$ \\
\hline L. inermis & $15.43 \pm 0.03^{* *}$ & $66.62 \pm 0.11^{*}$ & $10.814 \pm 0.01$ & $111.33 \pm 0.58$ \\
\hline M. acuminata & $8.80 \pm 0.10$ & $2.06 \pm 0.10$ & $0.613 \pm 0.01$ & $162.67 \pm 0.58$ \\
\hline M. communits & $5.30 \pm 0.05$ & $22.04 \pm 0.06$ & $2.12 \pm 0.01$ & $176.00 \pm 1.00$ \\
\hline P. nigrum & $9.20 \pm 0.10$ & $41.08 \pm 0.10^{*}$ & $4.91 \pm 0.01$ & $106.00 \pm 1.00$ \\
\hline P. dactylifera & $12.03 \pm 0.16^{*}$ & $49.75 \pm 0.05^{*}$ & $13.71 \pm 0.010^{*}$ & $52.00 \pm 1.00$ \\
\hline S. longena & $1.55 \pm 0.05$ & $9.97 \pm 0.15$ & $2.33 \pm 0.06$ & $91.67 \pm 0.58$ \\
\hline S. aromaticum & $9.3 \pm 0.05^{*}$ & $43.86 \pm 0.24 *$ & $2.73 \pm 0.01$ & $107.33 \pm 0.58$ \\
\hline V. vinifera & $8.25 \pm 0.05$ & $7.58 \pm 0.08$ & $0.914 \pm 0.01$ & $101.67 \pm 0.58$ \\
\hline
\end{tabular}

A. ampeloprasum: Allium ampeloprasum, A. graveolens: Anethum graveolens, C. sinesis: Camellia sinesis, C. annuum: Capsicum annuum, C. zeylanicum: Cinnamomum zeylanicum, C. colocynthis: Citrullus colocynthis, C. longa: Curcuma longa, L. inermis: Lawsonia inermis, M. acuminate: Musa acuminate, M. communits: Myrtus communits, P. nigrum: Piper nigrum, P. dactylifera: Phoenix dactylifera, S. melongena: Solanum melongena, S. aromaticum: Syzygium aromaticum, V. vinifera: Vitis vinifera, ** $\mathrm{p}=0.0005$, ${ }^{*} \mathrm{p}=0.01$ at a level $0.05, \mathrm{mg} \mathrm{GAE} / \mathrm{gDW}$ : Mg gallic acid equivalents per gram of dry weight, mg QE/gDW: Mg quercetin equivalent per gram dry weight, antioxidant activity was estimated as BATS IC ${ }_{50}$ values, which defined as the concentration of test material needed to scavenge $50 \%$ of ABTS radical present in the test solution. Lower $\mathrm{IC}_{50}$ value reflects high antioxidant activity. SD values of a minimum of 3 replicates, ABTS: 2,2-azinobis-(3-ethylbenzothiazoline-6-sulfonic acid), SD: Standard deviation, $\mathrm{IC}_{50}$ : Inhibitory concentration 50

The extraction system was used consisting of various ratios of ethanol and methanol by using the same previous extraction conditions, in addition to adding water: $\mathrm{HCl}$ at ratio 20:1 (v/v), that depending on previous studies $[15,16]$ which reported the best water ratio for the flavonoids and the phenolic extraction was 20:1 of water: $\mathrm{HCl}$.
The phenolic extraction was occurred in acidic solvents for recovering the bounded phenolic compounds from tissues [15].

Fig. 4 appeared the extraction yield of flavonoids and phenolics from both plants, and the best extraction system was EtOH:MeOH:HCl: $\mathrm{H}_{2} \mathrm{O}$ 
at a ratio 50:29:1:20 which gave the highest yield of flavonoids were $5.10 \pm 0.02$ and $4.48 \pm 0.02 \mathrm{mg} \mathrm{QE} / \mathrm{gDW}$ and phenolics were $40.75 \pm 0.05$ and $45.5 \pm 0.15 \mathrm{mg} \mathrm{GAE} / \mathrm{gDW}$ from A. ampeloprasum and C. colocynthis, respectively ( $p=0.000$ at a level 0.05$)$. Hence, this solvent system was used to extract flavonoids and phenolics from the other plants.

Table 2 showed the extraction percentage per gram dry weight of plant (\% of gDW) of 15 studied plants, which Lawsonia inermis had a highest percentage $(15.43 \pm 0.03 \%)$ of extract and S. melongena had a lowest percentage $(1.55 \pm 0.05 \%)$ for phenolic extractions. In addition, Table 2 revealed that the total phenolic compounds and flavonoids contents and the antioxidant activities of the extracts, which had ability to reduce the absorbance of ABTS free radical to half $\left(\mathrm{IC}_{50}\right)$ and referred as an inhibition percentage $\mathrm{PI} \%$. The results appeared that variation in phenolics and flavonoid contents and the antioxidant activities, however C. zeylanicum extract had highest phenolic content was $148.26 \pm 0.15 \mathrm{mg}$ GAE/gDW, followed L. inermis, C. colocynthis, Syzygium aromaticum, Piper nigrum, and Phoenix dactylifera were $66.62 \pm 0.11,45.5 \pm 0.15,43.86 \pm 0.24$, $41.08 \pm 0.10$, and $49.75 \pm 0.05 \mathrm{mg} \mathrm{GAE} / \mathrm{gDW}$, respectively, and the lowest phenolic content was $2.06 \pm 0.01 \mathrm{mg} \mathrm{GAE} / \mathrm{gDW}$ of $M$. acuminate extract. The extracts of $C$. zeylanicum, L. inermis and P. dactylifera had the highest flavonoid contents were $29.63 \pm 0.51,13.71 \pm 0.010$, and $10.814 \pm 0.01 \mathrm{mg}$ $\mathrm{QE} / \mathrm{gDW}$, respectively, whereas the M. acuminata had lowest flavonoid content was $2.12 \pm 0.01 \mathrm{mg} \mathrm{QE} / \mathrm{gDW}$. The antioxidant activity assay of these extracts appeared that the lowest estimated values $\mathrm{IC}_{50}$ which indicated the higher ability to scavenge $50 \%$ of free radicals in respect to the PI value of $\mu \mathrm{g} / \mathrm{ml}$ of plant extract, so $C$. longa, P. dactylifera, $C$. colocynthis, and $S$. melongena extracts $(48.67 \pm 0.58,52.00 \pm 1.00$, $87.33 \pm 1.53$, and $91.67 \pm 0.58 \mu \mathrm{g} / \mathrm{ml}$ of the extracts, respectively) had the highest ability to scavenge the free radicals, whereas A. graveolens $(720.67 \pm 0.53 \mu \mathrm{g} / \mathrm{ml})$ had the lowest ability.

Numerous published studies described significant and positive correlations between total phenolic content and the antioxidant activity [2,24]. However, Rivero-Pérez et al. [25] explain that antioxidant activity depends more on the structure and conformation of total phenolic compounds than their concentration. As the present study, the extraction results of $C$. longa, P. dactylifera, C. colocynthis, A. ampeloprasum, S. melongena which shown lower phenolic contents than C. zeylanicum, and they had highest antioxidant activities. Furthermore, the total phenolic compound was estimated according to the Folin-Ciocalteu method that may also determine other reducing compounds as reducing sugars [26] and react also with some nitrogen compounds as amino acids and amines [27]. The main disadvantage of spectrophotometric assays is that they only give an estimation of the total phenolic content. It does not separate nor does it give a quantitative measurement of individual compounds. Similarly, the molecular antioxidant response of phenolic compounds in plants varies remarkably, depending on their chemical structure [25]. Thus, the antioxidant activity of an extract cannot be predicted on the basis of its total phenolic content.

In this study, all studied plant extracts exhibited different phenolic and flavonoid contents for example A. ampeloprasum had a higher total phenolic content (40.75 mg GAE/gDW) than the total phenolic contents reported by Garcia-Herrera et al. [28] in the whole leek plant was $5.77 \mathrm{mg}$ GAE/g fresh weight, whereas Ben Arfa et al. [29] found that the wild species of A. ampeloprasum had variable bioactive compounds such as the total polyphenol (16.64-48.22 mg GEA/gDM), flavonoid (1.01-5.84 mg $\mathrm{CE} / \mathrm{gDM}$ ), and tannin (3.47-7.62 mg CE/gDM) contents and antioxidant activities (2,2-diphenyl-1-picrylhydrazyl [DPPH] and iron chelating power) were strongly affected by the environmental condition on these characteristic have been scarcely known. Whereas our result revealed that the total phenolic and flavonoid contents of the $C$. zeylanicum.

The bark was slightly lower $(148.26 \pm 0.15 \mathrm{mg}$ GAE/gDW and $29.63 \pm 0.51 \mathrm{mg}$ QE/gDW) than Varalakshmi et al. [30] results who reported that $C$. zeylanicum bark is a nutraceutical rich in phenolic antioxidants, and the total phenolic content was $153.33 \pm 23.09 \mathrm{mg}$ of pyrocatechol equivalents/g, and flavonoids was $33.66 \pm 1.15 \mathrm{mg}$ of catechin equivalents/g of powdered bark. Whereas the phenolic and flavonoid contents and antioxidant activity of $C$. longa were lower than the contents that reported by Alafiatayo et al. [31] who found $42.71 \mathrm{mg} \mathrm{GAE} / \mathrm{gDW}, 741.36 \mathrm{mg} \mathrm{NGN/gDW}$ and it had the highest free radical scavenging capacity of $270.07 \mathrm{mg} \mathrm{TE} / \mathrm{gDW}$, respectively. The differences of results were related to the extraction solvent type and conditions which extracted by $100 \%$ methanol with refluxed at $60^{\circ} \mathrm{C}$, in addition to the estimation methods of flavonoid and antioxidant activity were different which, depending on mg naringenin equivalents $(\mathrm{Ng}) / \mathrm{g}$ samples and used DPPH to determine the free radical scavenging capacity. In addition, the plant age is very important due to its effects on phenolic contents; Alafiatayo et al. [31] used fresh and young rhizomes which were harvested after 1 month of growth, whereas our results depending on different extraction solvents and conditions, also the rhizomes not fresh; they were imported from original countries and stored under conventional conditions. Similar results reported by Sahu and Saxena [32] how found the total phenolic content was $260 \pm 0.25 \mathrm{mg}$ GAE/gDW and 79.36 $\pm 0.01 \mathrm{mg} \mathrm{CE} / \mathrm{gDW}$ of the total flavonoid content which extracted from $C$. longa by methanol. The other results of the phenolic and flavonoid contents of the rest studied plants such as $P$. dactylifera, A. graveolens, C. sinensis, C. annuum, C. colocynthis, L. inermis, M. acuminata, M. communits, P. nigrum, S. melongena, S. aromaticum, and $V$. vinifera were different or in agreement with previous results depending on extraction methods, extraction solvents and conditions, plant age, the estimation methods of phenolics, flavonoids and antioxidant activities, so on [33-45].

Overall, the variations in the chemical composition of the selected plants, as in other plant tissues may be due to the multiple influences of different factors such as temperature, age, storage conditions, precipitation, sun exposure, soil composition, growing status, and the interaction of the other plants or animals in the ecosystem [30]. Unfavorable environmental conditions (salinity, drought, heat/cold, luminosity, and other hostile conditions) may trigger oxidative stress in plants, generating the formation of ROS, leading to cellular damage, metabolic disorders, and senescence processes $[46,47]$.

The extracts of $P$. dactylifera, $C$. colocynthis, and S. melongena were selected depending on antioxidant activity to study their effects on

Table 3: Partial purification of plant extracts by adsorption chromatography using a silica gel column

\begin{tabular}{|c|c|c|c|}
\hline Plant & Steps & $\begin{array}{l}\text { Total phenolics } \\
\text { (mg GAE } \pm \text { SD) }\end{array}$ & $\begin{array}{l}\text { Total flavonoids } \\
\text { (mg QE } \pm \text { SD) }\end{array}$ \\
\hline \multirow[t]{6}{*}{ P. dactylifera } & Crude extract & $3578 \pm 2.577$ & $284 \pm 1.012$ \\
\hline & $95 \%$ ethanol & $530 \pm 1.201$ & $30 \pm 0.577$ \\
\hline & $70 \%$ acetone & $441 \pm 1.120$ & $190.5 \pm 1.130$ \\
\hline & $30 \%$ acetone & $80 \pm 1.021$ & $24.5 \pm 0.577$ \\
\hline & $\mathrm{H}_{2} \mathrm{O}$ & $1075 \pm 2.155$ & 0 \\
\hline & Recovery \% & 59.42 & 85.91 \\
\hline \multirow[t]{6}{*}{ C. colocynthis } & Crude extract & $277.2 \pm 1.577$ & $37.8 \pm 0.577$ \\
\hline & $95 \%$ ethanol & $72.35 \pm 0.577$ & $2.9 \pm 0.012$ \\
\hline & $70 \%$ acetone & $148 \pm 1.051$ & $20 \pm 0.577$ \\
\hline & $30 \%$ acetone & $39 \pm 0.152$ & $3.61 \pm 0.012$ \\
\hline & $\mathrm{H}_{2} \mathrm{O}$ & $4.48 \pm 0.122$ & 0 \\
\hline & Recovery \% & 95.18 & 70.13 \\
\hline \multirow[t]{6}{*}{ S. melongena } & Crude extract & $434.50 \pm 2.012$ & $96.55 \pm 0.577$ \\
\hline & $95 \%$ ethanol & $228.40 \pm 1.055$ & $10.60 \pm 0.012$ \\
\hline & $70 \%$ acetone & $154.50 \pm 1.557$ & $60.28 \pm 1.150$ \\
\hline & $30 \%$ acetone & $21.06 \pm 0.577$ & $0.78 \pm 0.012$ \\
\hline & $\mathrm{H}_{2} \mathrm{O}$ & $15.35 \pm 0.252$ & $0.51 \pm 0.011$ \\
\hline & Recovery & 96.50 & 74.75 \\
\hline
\end{tabular}

C. colocynthis: Citrullus colocynthis, S. melongena: Solanum melongena, $P$. dactylifera: Phoenix dactylifera, GAE: Gallic acid equivalents, SD: Standard deviation. Total phenolics and total flavonoids were expressed as mg GAE \pm SD and $\mathrm{mg} \mathrm{QE} \pm \mathrm{SD}$ which resulted from $\mathrm{mg} \mathrm{GAE} / \mathrm{ml}$ x total volume $(\mathrm{ml})$ of fractions and $\mathrm{mg} \mathrm{QE} / \mathrm{ml} \mathrm{x}$ total volume of fractions $(\mathrm{ml}), \mathrm{H}_{2} \mathrm{O}$ : Distilled water. Each fractionation was replicated three times 
Table 4: The cytotoxic activity of partially purified plant extracts against the breast cancer cell line MCF-7 and the non-tumorigenic fetal hepatic cell line WRL-68

\begin{tabular}{|c|c|c|c|c|c|c|}
\hline \multirow{2}{*}{$\begin{array}{l}\text { Partially purified } \\
\text { phenolics }\end{array}$} & \multirow{2}{*}{$\begin{array}{l}\text { Concentration } \\
(\mu \mathrm{g} / \mathrm{ml})\end{array}$} & \multicolumn{2}{|l|}{ Total amount } & \multicolumn{2}{|c|}{$\%$ Cell viability mean \pm SE } & \multirow{2}{*}{$\begin{array}{l}\text { T-test } \\
\text { value }(p<0.05)\end{array}$} \\
\hline & & Phenolics $(\mu \mathrm{g}$ AGE/ml) & Flavonoids ( $\mu \mathrm{g} \mathrm{QE} / \mathrm{ml})$ & MCF-7 & WRL-68 & \\
\hline \multirow[t]{3}{*}{ P. dactylifera } & 100 & 77.68 & 33.56 & $60.79 \pm 3.45$ & $72.38 \pm 2.35$ & \multirow[t]{3}{*}{0.000} \\
\hline & 50 & 38.84 & 16.78 & $77.27 \pm 3.97$ & $91.08 \pm 3.68$ & \\
\hline & 25 & 19.42 & 8.39 & $84.97 \pm 2.64$ & $93.93 \pm 3.57$ & \\
\hline \multirow[t]{3}{*}{ C. colocynthis } & 100 & 62.40 & 8.43 & $94.93 \pm 3.01$ & $68.22 \pm 2.21$ & \multirow[t]{3}{*}{0.000} \\
\hline & 50 & 31.20 & 4.22 & $98.55 \pm 1.08$ & $95.82 \pm 3.54$ & \\
\hline & 25 & 15.60 & 2.11 & $101.36 \pm 0.98$ & $101.77 \pm 4.01$ & \\
\hline \multirow{3}{*}{ S. melongena } & 100 & 98.94 & 38.6 & $88.23 \pm 1.20$ & $88.25 \pm 0.20$ & \multirow[t]{3}{*}{0.265} \\
\hline & 50 & 49.47 & 19.3 & $92.47 \pm 2.35$ & $89.83 \pm 2.34$ & \\
\hline & 25 & 24.735 & 9.65 & $93.74 \pm 3.87$ & $92.23 \pm 1.25$ & \\
\hline
\end{tabular}

C. colocynthis: Citrullus colocynthis, S. melongena: Solanum melongena, P. dactylifera: Phoenix dactylifera, MCF: Michigan Cancer Foundation-7, SE: Standard error. Each measurement was replicated 3 times

cancer cell lines after flavonoids were partially purified by adsorption chromatography using a silica gel column. In addition to these plants is rarely studied and abundant in Iraq, particularly P. dactylifera.

Partial purification was accomplished by adsorption chromatography using a silica gel column the loading solvents were $95 \%$ ethanol, and the elution solvents were $70 \%$ acetone followed $30 \%$ acetone and then pure water respectively, using the batch ways method. Each solvent was added at $500 \mathrm{ml}$ or more depending on the reading value of the absorbance at $280 \mathrm{~nm}$ when it became between 0.000 and 0.001 , then the next followed solvent was added. After that, the total flavonoids and phenolics estimated for each fraction. In this study, we focused on hydrophobic phenolics especially that related to flavonoids because the members of this group have antioxidant, anti-inflammatory, and anticarcinogenic effects and it decreases the fragility of blood vessels like rutin, also known as vitamin $\mathrm{P}[2,6,48,49]$.

In the present results, the purification of phenolic and flavonoid extracts of the selected plants P. dactylifera, C. colocynthis, and $S$. melongena by adsorption chromatography using the silica gel column appeared varied amounts of phenolics and flavonoids that separated using different concentrations of solvents as shown in Table 3. From these results, the most of the phenolic content of $P$. dactylifera was eluted by DW (soluble in water), and the most flavonoid content was eluted by $70 \%$ acetone, whereas the most phenolics and flavonoids of C. colocynthis were eluted by $70 \%$ acetone. Most of phenolics and flavonoids of $S$. melongena were eluted by $95 \%$ ethanol and $70 \%$ of acetone, respectively (Table 3). These results were in agreement with previous studies that used a silica gel column in phenolics purification $[15,16,49]$.

The cytotoxic activity of the partial purified extracts was assayed using two cell lines, including breast cancer cell line MCF-7 and the normal human hepatic cells (non-tumorigenic fetal hepatic cell line WRL-68). The selected partially purified extracts $(70 \%$ acetone fractions which mostly contain flavonoids) were used in the concentrations ranged from 25 to $100 \mu \mathrm{g} / \mathrm{ml}$ for in vitro evaluating to select the best effective plant extract against cell lines, and subsequent study will focus on its preventive effects against induced mammary cancer in a rat model. The results revealed that all selected extracts had variable effects on $\%$ cell viability (Table 4 ). From the results, the partially purified seed extract of $P$. dactylifera had the best cytotoxic effect on the cancer cell line MCF-7 at concentration $100 \mu \mathrm{g} / \mathrm{ml}$ followed $50 \mu \mathrm{g} / \mathrm{ml}$ and it had less effect on the normal cell line WRL-68 especially at $50 \mu \mathrm{g} / \mathrm{ml}$ $(\mathrm{p}<0.05)$, and the minimum inhibition dose that kills approximately $50 \%$ of cells $\left(\mathrm{IC}_{50}\right)$ at $24 \mathrm{~h}$ was $202 \mu \mathrm{g} / \mathrm{ml}(156.91 \mu \mathrm{g}$ phenolics) for MCF-7 and $480 \mu \mathrm{g} / \mathrm{ml}$ (372.86 $\mu \mathrm{g}$ phenolics) for WRL-68. Whereas the extracts of $C$. colocynthis had cytotoxic effects on the normal cell line more than breast cancer cell line $(\mathrm{p}<0.05)$. The $\mathrm{IC}_{50}$ value for MCF-7 was $1690.8 \mu \mathrm{g} / \mathrm{ml}(1055.06 \mu \mathrm{g}$ phenolics $)$ of C. colocynthis extract, and the $\mathrm{IC}_{50}$ value for WRL-68 was $246.51 \mu \mathrm{g} / \mathrm{ml}$ (153.8 $\mu \mathrm{g}$ phenolics) respectively. While the extract of $S$. melongena had the same effects on cancer and normal cell lines ( $\mathrm{p}=0.265)$, and the $\mathrm{IC}_{50}$ was very wide which was $58528 \mu \mathrm{g} / \mathrm{ml}$ (57907.6 $\mu \mathrm{g}$ phenolics) for both cell lines. The results indicate the phenolic extract of $P$. dactylifera was the best compared with other plant extracts because it had cytotoxic effects against cancer cell line more than the normal cell line.

These results were in agreement with [50] who showed that the P. dactylifera seed extract had anticancer activity against Ehrlich ascites carcinoma cells

The antiproliferative effect of cucurbitacin glycosides extracted from C. colocynthis leaves was studied in human breast cancer cell growth. The leaves were extracted and cucurbitacin B/E glycosides were isolated from the extract. The cucurbitacin glycoside combination (1:1) inhibited growth of ER+ MCF-7 and ER- MDA-MB- 231 human breast cancer cell lines $[51,52]$ in comparison with our study that we used the C. colocynthis fruits. Whereas, S. melongena extract had a low cytotoxic effect against cell lines, and these results were in agreement with the previous studies $[43,53]$.

\section{CONCLUSION}

The phenolic compounds act as antioxidant substances which had variable effectiveness on normal cell and cancer cell lines, and the highest concentrations were toxic to normal cells and cancerous poison impact may be on normal cells over than the cancerous cells.

\section{ACKNOWLEDGMENT}

The authors are thankful to Pioneer Projects Department, Research and Development Directorate, Ministry of Higher Education and Scientific Research, Iraq, for funding this research which was done at the Laboratory of Biotechnology and Genetic Engineering, Department of Biology, College of Science, University of Babylon, Iraq.

\section{REFERENCES}

1. Bernhoft A. A brief review on bioactive compounds in plants. In: Bernhoft A, editor. Bioactive Compounds in Plants - Benefits and Risks for Man and Animals. Oslo: The Norwegian Academy of Science and Letters; 2010. p. 11-7.

2. Blomhoff R. Role of dietary phytochemicals in oxidative stress. In: Bernhoft A, editor. Bioactive Compounds in Plants - Benefits and Risks for Man and Animals. Oslo: The Norwegian Academy of Science and Letters; 2010. p. 52-70.

3. Luk'yanova LD, Storozheva ZI, Proshin AT. Corrective effect of flavonoid-containing preparation extralife on the development of Parkinson's syndrome. Bull Exp Biol Med 2007;144(1):42-5.

4. Seelinger G, Merfort I, Wölfle U, Schempp CM. Anti-carcinogenic effects of the flavonoid luteolin. Molecules 2008:13:2628-51.

5. Kale MA, Bindu SM, Khadkikar P. Role of antioxidants and nutrition in oxidative stress: A review. Int J Appl Pharm 2015;7:1-4

6. Dai J, Mumper RJ. Plant phenolics: Extraction, analysis and their 
antioxidant and anticancer properties. Molecules 2010;15(10):7313-52.

7. Fimognari C, Berti F, Nusse M, Cantelli Forti G, Hrelia P. In vitro antitumor activity of cyanidin-3-O-beta-glucopyranoside. Chemotherapy 2005;51(6):332-5.

8. Ogasawara M, Matsunaga T, Suzuki H. Differential effects of antioxidants on the in vitro invasion, growth and lung metastasis of murine colon cancer cells. Biol Pharm Bull 2007;30(1):200-4.

9. Ramos S. Effects of dietary flavonoids on apoptotic pathways related to cancer chemoprevention. J Nutr Biochem 2007;18(7):427-42.

10. Ghasemzadeh A, Jaafar HZ. Anticancer and antioxidant activities of Malaysian young ginger (Zingiber officinale Roscoe) varieties grown under different $\mathrm{CO}$ concentration. J Med Plant Res 2011;5:3247-55.

11. Thangapazham RL, Singh AK, Sharma A, Warren J, Gaddipati JP, Maheshwari RK. Green tea polyphenols and its constituent epigallocatechin gallate inhibits proliferation of human breast cancer cells in vitro and in vivo. Cancer Lett 2007;245(1-2):232-41.

12. Zhang Y, Seeram NP, Lee R, Feng L, Heber D. Isolation and identification of strawberry phenolics with antioxidant and human cancer cell antiproliferative properties. J Agric Food Chem 2008;56(3):670-5.

13. White B, Rice L, Howard LR. The procedure, principle, and instrumentation of antioxidant phytochemical analysis. In: $\mathrm{Xu} \mathrm{Z}$, Howard LR, editors. Analysis of Antioxidant-Rich Phytochamicals. $1^{\text {st }}$ ed. UK: Wiley-Blackwell, Wiley \& Sons, Ltd.; 2012. p. 25-68.

14. Pavia DL, Lampman GM, Kriz GS, Vyvyan JR. Microscale and Macroscale Techniques in the Organic Laboratory. USA: Brooks/Cole; 2002

15. Toma's-Barbera'n FA, Ferreres F. Analytical methods of flavonols and flavones. In: Xu Z, Howard LR, editors. Analysis of Antioxidant-Rich Phytochamicals. $1^{\text {st }}$ ed. UK: Wiley-Blackwell, Wiley \& Sons, Ltd.; 2012. p. 207-46.

16. Xu Z. Analysis method of phenolic acids. In: Xu Z, Howard LR, editors. Analysis of Antioxidant-Rich Phytochamicals. $1^{\text {st }}$ ed. UK: Wiley-Blackwell, Wiley \& Sons, Ltd.; 2012. p. 69-104.

17. Chaves TP, Santana CP, Véras G, Brandão DO, Felismino DC, Medeiros AC, et al. Seasonal variation in the production of secondary metabolites and antimicrobial activity of two plant species used in Brazilian traditional medicine. Afr J Biotechnol 2013;12:847-53.

18. Budrat P, Shotipruk A. Enhanced recovery of phenolic compounds from bitter melon (Momordica charantia) by subcritical water extraction. Sep Purif Technol 2009;66:125-9.

19. Sharma R, Chandan G, Chahal A, Saini RV. Antioxidant and anticancer activity of methanolic extract from Stephania elegans. Int J Pharm Pharm Sci 2017;9:245-9.

20. Freshney RI. Culture of Animal Cell. $6^{\text {th }}$ ed. New York: Wily-Liss; 2010.

21. Liu CP, Tsai WJ, Lin YL, Liao JF, Chen CF, Kuo YC. The extracts from Nelumbo Nucifera suppress cell cycle progression, cytokine genes expression, and cell proliferation in human peripheral blood mononuclear cells. Life Sci 2004;75(6):699-16

22. Rostagno MA, Palma M, Barroso CG. Microwave assisted extraction of soy isoflavones. Anal Chim Acta 2007;588(2):274-82.

23. Mudgett RE. Electrical properties of foods. In: Rao MA, Rizvi SS, editors. Engineering Properties of Foods. $2^{\text {nd }}$ ed. New York: Marcel Dekker Inc.; 1995. p. 389-55.

24. Giovanelli G, Brambilla A, Rizzolo A, Sinelli N. Effects of blanching pre-treatment and sugar composition of the osmotic solution on physico-chemical, morphological and antioxidant characteristics of osmodehydrated blue berries. Food Res Int 2012;49:263-71.

25. Rivero-Pérez MD, Muñiz P, Gonzalez-Sanjosé ML. Antioxidant profile of red wines evaluated by total antioxidant capacity, scavenger activity, and biomarkers of oxidative stress methodologies. J Agric Food Chem 2007;55(14):5476-83.

26. Vinson JA, Proch J, Bose P. Determination of quantity and quality of polyphenol antioxidants in foods and beverages. Methods Enzymol 2001;335:103-14.

27. Ikawa M, Schaper TD, Dollard CA, Sasner JJ. Utilization of Folin-Ciocalteu phenol reagent for the detection of certain nitrogen compounds. J Agric Food Chem 2003;51(7):1811-5.

28. Garcia-Herrera P, Morales P, Fernandez-Ruiz V, Sanchez-Mata MC, Camara M, Carvalho AM, et al. Nutrients, phytochemicals and antioxidant activity in wild populations of Allium ampeloprasum L., a valuable underutilized vegetable. Food Res Int 2014;62:272-9.

29. Arfa AB, Najjaa H, Yahia B, Tlig A, Neffati M. Antioxidant capacity and phenolic composition as a function of genetic diversity of wild Tunisian leek (Allium ampeloprasum L.). J New Sci 2015;21:957-68.
30. Varalakshmi B, Anand V, Kumar S. In vitro biomoleculr protective effect of Cinnamomum zeylanicum bark extracts against oxidative damage. Int J Pharm Pharm Sci 2016;8:369-72.

31. Alafiatayo AA, Syahida A, Mahmood M. Total anti-oxidant capacity, flavonoid, phenolic acid and polyphenol content in ten selected species of Zingiberaceae rhizomes. Afr J Tradit Complement Altern Med 2014;11(3):7-13.

32. Sahu R, Saxena J. Screening of total phenolic and flavonoid content in conventional and non-conventional species of curcuma. J Pharmacogn Phytochem 2013;2:176-9.

33. Ksouri A, Dob T, Belkebir A, Lamari L, Krimat S, Metidji H. Total phenolic, antioxidant, antimicrobial activities and cytotoxicity study of wild Anethum graveolens L. Int J Pharmacogn Phytochem Res 2015;7:1025-32.

34. Unachukwu UJ, Ahmed S, Kavalier A, Lyles JT, Kennelly EJ. White and green teas (Camellia sinensis Var. Sinensis): Variation in phenolic, methylxanthine, and antioxidant profiles. J Food Sci 2010;75(6):C541-8.

35. Wetwitayaklung P, Phaechamud T. Antioxidant activities and phenolic content of Solamun and Capsicum sp. Res J Pharm Biol Chem Sci 2011;2:146-54

36. Hussain AI, Rathore HA, Sattar MZ, Chatha SA, Ahmad F, Ahmad A, et al. Phenolic profile and antioxidant activity of various extracts from Citrullus colocynthis (L.) from the Pakistani flora. Ind Crops Prod 2013;45:416-22.

37. Uma DB, HO CW, Aida WM. Optimization of extraction parameters of total phenolic compounds from Henna (Lawsonia inermis) leaves. Sains Malays 2010;39:119-28.

38. Prakash D, Suri S, Upadhyay G, Singh BN. Total phenol, antioxidant and free radical scavenging activities of some medicinal plants. Int $\mathrm{J}$ Food Sci Nutr 2007;58(1):18-28.

39. Kumar OA, Rao SA, Tata SS. Phenolics quantification in some genotype of Capsicum annuum L. J Phytol 2010;2:87-90.

40. Babu MA, Suriyakala MA, Gothandam KM. Varietal impact on phytochemical contents and antioxidant properties of Musa acuminata (banana). J Pharm Sci Res 2012;4:1950-5.

41. Wannes WA, Marzouk B. Differences between Myrtle fruit parts (Myrtus communis Var. Italica) in phenolics and antioxidant contents. J Food Biochem 2013;37:585-94.

42. Gülçin I. The antioxidant and radical scavenging activities of black pepper (Piper nigrum) seeds. Int J Food Sci Nutr 2005;56(7):491-9.

43. Choirunnisa AR, Fidrianny I, Ruslan K. Comparison of five antioxidant assays for estimating antioxidant capacity from three Solanum sp. Extracts. Asian J Pharm Clin Res 2016;9 Suppl 2:123-8.

44. El-Maatia MF, Mahgoubb SA, Labiba SM, Al-Gabya AM, Ramadan MF. Phenolic extracts of clove (Syzygium aromaticum) with novel antioxidant and antibacterial activities. Eur J Integr Med 2016. DOI: 2016.02.006

45. Sravanthi J, Gangadhar RS. Quantification of antioxidantPhytochemical studies in Vitis vinifera. L. Varieties. Asian J Pharm Clin Res 2015;8:295-301.

46. Menezes L, Teixeira FK, Alvim CL, Margis-Pinheiro M. Salt stress induces altered expression of genes encoding antioxidant enzymes in seedlings of a Brazilian indica rice (Oryza sativa L.). Plant Sci 2004;166:323-31.

47. Menezes-Benavente L, Kernodle SP, Margis-Pinheiro M, Scandalios JG. Salt-induced antioxidant metabolism defenses in maize (Zea mays L.) seedlings. Redox Rep 2004;9(1):29-36

48. Sandhar HK, Kumar B, Prasher S, Tiwari P, Salhan M, Sharma P. A review of phytochemistry and pharmacology of flavonoids. Int Pharm Sci 2011;1:25-41.

49. Ammar AS, Habiba RA. Phenolic content and antioxidant activity of date seeds. J Agric Vet Sci Qassim Univ 2010;3:3-8

50. Abou-Elella F, Mourad R. Anticancer and anti-oxidant potentials of ethanolic extracts of Phoenix dactylifera, Musa acuminata and Cucurbita maxima. Res J Pharm Biol Chem Sci 2015;6:710-20.

51. Tannin-Spitz T, Grossman S, Dovrat S, Gottlieb HE, Bergman M. Growth inhibitory activity of cucurbitacin glucosides isolated from Citrullus colocynthis on human breast cancer cells. Biochem Pharmacol 2007;73(1):56-67.

52. Mehni AM, Shahdadi F. Phenolic compounds and antiradical properties of methanolic extracts of Citrullus colocynthis and Plantago major in Iran. Int J Biosci 2014;4:224-8.

53. Cham BE. Drug therapy: Solamargine and other solasodine rhamnosyl glycosides as anticancer agents. Mod Chemother 2013;2:33-49. 